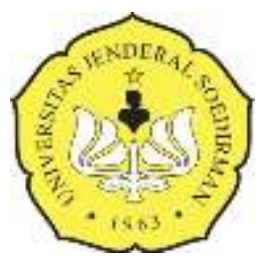

PAJU Volume 1 Nomor 12019

PHYSICAL ACTIVITY JOURNAL

http://jos.unsoed.ac.id/index.php/paju

\title{
Pengaruh Model Pembelajaran Kooperatif Tipe Teaching Games For Understanding (TGFU) Terhadap Peningkatan Hasil Belajar Teknik Dasar Sepakbola
}

\author{
Wildan Qohhar ${ }^{1}$, Deni Pazriansyah²
}

1,2 STKIP Situs Banten, Indonesia

email: wildan.qohhar@stkipsitusbanten.ac.id ${ }^{1}$, deni.pazriansyah@stkipsitusbanten.ac.id²

DOI: https://doi.org/10.20884/1.paju.2019.1.1.1998

\begin{abstract}
Abstrak
Teaching Games for Understanding (TGFU) merupakan model pembelajaran yang menekankan taktik pemainan untuk dapat dimengerti sebagai pengenalan pertama, siswa harus mengetahui kenapa dan kapan keterampilan itu diperlukan dalam konteks permainan, pelaksanaan teknis dalam keterampilan, khususnya pada teknik dasar sepakbola. Penelitian ini menggunakan metode ekperimen yang dilaksanakan selama 16 pertemuan yang dilaksanakan 3 kali seminggu, jadi penelitian dilakukan kurang lebih selama 6 minggu.Instrumen penelitian yang digunakan yaitu tes teknik dasar sepakbola yang terdiri dari passing, dribbling dan shooting. Sampel pada penelitian ini yaitu siswa SMA 3 kota Serang Banten dengan jumlah 40 orang. Hasil penelitian menunjukan bahwa berdasarkan uji Two Related Sample tests pada data pre-test dan post-test pada kelompok yang menggunakan pembelajaran TGFU menunjukan nilai signifikansi sebesar 0,000 . Karena signifikansi pada data pre-test dan posttest pada kelompok yang menggunakan pembelajaran TGFU $<0,05$ maka dapat disimpulkan bahwa terdapat pengaruh pemberian model pembelajaran TGFU terhadap keterampilan teknik dasar sepakbola.
\end{abstract}

Kata Kunci: Model Pembelajaran, Kooperatif, TGFU, Teknik Dasar Sepakbola

\begin{abstract}
Teaching Games for Understanding (TGFU) is a instructional model that emphasizes game tactics to be understood as the first introduction, students must know why and when skills are needed in the context of the game, the technical implementation of skills, especially in basic soccer techniques. This study used an experimental method which was conducted for 16 meetings held 3 times a week, so the study was conducted for approximately 6 weeks. The research instrument used was a basic football technical test consisting of passing, dribbling and shooting. The sample in this study were 3 Senior High School students in Serang Banten city with a total of 40 people. The results showed that based on the Two Related Sample tests on pre-test and post-test data in groups using TGFU learning showed a significance value of 0,000. Because of the significance of the pre-test and post-test data in groups using TGFU learning $<0.05$, it can be concluded that there is an effect of giving TGFU learning models to basic technical skills of football.
\end{abstract}

Keywords: Instructional Model, Cooperative, TGFU, Basic Soccer Techniques

\begin{tabular}{|c|c|c|c|}
\hline Alamat Koresponden & Prodi PJKR STKIP Situs Banten & $\begin{array}{l}\text { e-ISSN } \\
\text { p-ISSN }\end{array}$ & $\begin{array}{l}: 2686-5807 \\
: 2686-5793\end{array}$ \\
\hline $\begin{array}{l}\text { E-mail } \\
\text { No. Telp./Hp }\end{array}$ & wildan.qohhar@stkipsitusbanten.ac.id & & \\
\hline
\end{tabular}




\section{PENDAHULUAN}

Kegiatan belajar mengajar di sekolah, khususnya mata pelajaran pendidikan jasmani merupakan proses belajar yang memanfaatkan berbagai aktifitas jasmani atau fisik untuk memperoleh tujuan pembelajaran. (Budi, Hidayat, \& Febriani, 2019) menjelaskan bahwa Pendidikan jasmani merupakan salah satu mata pelajaran yang wajib diikuti oleh siswa sebagai sarana bagi siswa untuk dapat mengembangkan potensi diri melalui berbagai aktifitas fisik. Salah satunya berbentuk aktivitas jasmani yang diajarkan di ssekolah yaitu olahraga permainan, sehingga dalam penyampaian materi pelajaran pun dapat dilakukan melalui aktivitas bermain. Salah satu materi olahraga permainan yang wajib dan terdapat dalam kurikulum penjas di sekolah adalah mata pelajaran sepak bola

Pembelajaran sepakbola yang dikembangkan dalam kurikulum pendidikan jasmani, baik melalui program intrakurikuler maupun ekstrakurikuler, tidak hanya mengajarkan siswa untuk belajar mengenai berbagai teknik dasar atau cara bermain sepakbola, akan tetapi lebih dari itu siswa dapat menumbuh kembangkan berbagai sikap sosial dalam dirinya. Oleh karena, sepakbola memiliki kedudukan yang penting dalam kurikulum pendidikan jasmani di sekolah.

(Sucipto, 2000) menjelaskan bahwa Sepakbola merupakan permainan beregu, masing masing regu terdiri dari sebelas pemain, dan salah satunya penjaga gawang. Permainan ini hampir seluruhnya dimainkan dengan mengunakan tungkai, kecuali penjaga gawang yang dibolehkan menggunakan lenganya di daerah tendangan. Dalam perkembaganya permainan ini dapat dimainkan di luar lapangan ( out door ) dan di dalam ruangan tertutup ( in door ).Tujuan utama dari permainan sepak bola adalah memasukan bola ke gawang lawan sebanyak banyaknya dengan sportif yang sesuai dengan peraturan yang disepakati dan berusaha mencegah lawan memasukan bola ke gawang yang di jaga.

Untuk mampu mencapai tujuan bermain sepakbola tersebut diperlukan teknik tertentu dalam memainkan bola. Yang termasuk teknik dasar sepakbola adalah mengumpan bola (passing), menggiring bola (dribbling) dan menendang bola (shooting). Agar permainan bola menjadi lebih dinamis dan menarik maka teknik dasar itu dimainkan dalam bentuk bentuk bermain baik melalui taktik dan strategi menyerang maupun bertahan. Kemampuan siswa menguasai teknik dasar permainan sepakbola dapat mendukung penampilannya dalam permainan sepakbola baik secara individu maupun secara kolektif.

Pentingnya pembelajaran sepakbola yang telah menjadi salah satu materi wajib bagi siswa, dalam pelaksanaannya dipengaruhi oleh berbagai faktor yang dapat mendukung pembelajaran sepakbola menjadi lebih efektif. Faktor-faktor tersebut diantaranya yaitu guru, sarana dan prasarana dan siswa itu sendiri. Guru merupakan fondasi penting dalam pencapaian kesuskses pembelajaran. Pembelajaran akan dapat berjalan baik dan efektif apabila guru memiliki wawasan yang luas, kreatifitas dan penggunaan model pembelajaran yang tepat. 
Akan tetapi pada kenyataan di lapangan tidak semua guru dapat melaksanakan tugasnya dengan baik dikarenakan minimnya sarana dan prsarana yang dimiliki sekolah dan juga karena jumlah siswa yang terlalu banyak, siswa yang hiper aktif dan ada juga siswa yang kurang aktif, jadi pada waktu guru menyampaikan materi, siswa tidak dapat mengamati dan mengikuti pembelajaran yang diberikan, kurangnya kemampuan teknik dasar, sehingga guru tidak dapat mengkontrol aktivitas siswa yang pada akhirnya dapat mengganggu pembelajaran. (Budi, 2015) Inovasi dan modifikasi muncul dalam pendidikan jasmani pada hakekatnya disebabkan karena adanya ketidak seimbangan antara tuntutan materi yang harus diajarkan dengan jumlah waktu, sarana yang terseedia dan jumlah siswa yang banyak. Salah bentuk inovasia dan modifikasi yang dapat diterapkan oleh guru dalam pembelaajran penjas yaitu dengan cara menerapkan model pembelajaran yang tepat dalam mengajarkan materi permainan sepakbola.

Selama ini model yang digunakan oleh guru dalam pembelajaran sepakbola adalah model pembelajaran konvensional. Dengan model pembelajaran seperti ini biasanya siswa mengalami kejenuhan dan mengeluh karena mereka akan banyak mengalami kesulitan, sehingga dapat menyita waktu proses pembelajaran penjas, hal ini perlu dicarikan jalan keluar dengan memanfaatkan model pembelajaran yang dapat membantu proses belajar mengajar dan membuat siswa lebih termotivasi dalam mengikuti kegiatan pembelajaran, seperti model pembelajaran kooperatif antara lain tipe Jigsaw, tipe Think Pair Share (TPS), tipe Numbered Head Together (NHT), Teams Games Tournament (TGT), Teaching Games for Understanding (TGFU) dan sebagainya.

Dalam upaya untuk mencapai tujuan penjas melalui pembelajaran sepakbola, model pembelajaran kooperatif disarankan untuk diterapkan kepada siswa, karena menurut (Lickona, 2012) pembelajaran kooperatif mengajarkan nilai moral dan pengetahuan akademis secara bersamaan, sebagaimana yang dikatakan bahwa: "Ambillah apa yang biasanya anda ajarkan, ajarkan dengan cara belajar kooperatif paling sedikit pada satu bagian dari hari atau periode, dan anda akan mengajarkan nilai moral dan akademik pada waktu yang bersamaan". Selanjutnya (Slavin, 2008) memandang model pembelajaran kooperatif menyumbangkan ide bahwa siswa yang bekerjasama dalam belajar dan bertanggung jawab terhadap teman satu timnya mampu membuat mereka belajar sama baiknya.

Penelitian Snider 1986 dalam (Solihatin \& Raharjo, 2011) menemukan bahwa, penggunaan model cooperative learning sangat mendorong peningkatan prestasi belajar siswa hingga perbedaan hampir $25 \%$ dengan kemajuan yang dicapai oleh siswa yang diajar dengan menggunakan system kompetisi. Selain itu, (Slavin, 2008) menyatakan bahwa, 'model pembelajaran kooperatif dengan memakai konsep penghargaan tim dan tanggung jawab individu, dapat meningkatkan prestasi kemampuan dasar'.

Salah satu model pembelajaran kooperatif yang dapat diterapkan dalam proses pembelajaran sepakbola yaitu dengan menggunakan model Teaching Games For Understanding (TGFU) untuk menciptakan pembelajaran yang efektif dan membantu siswa dalam menguasai teknik dasar permainan sepakbola. TGFU adalah suatu pola pembelajaran dengan lebih menekankan pada pemahaman tentang 
permainan. Bunker dan Thrope (1986) dalam (Metzler, 2000) menjelaskan bahwa Model pembelelajaran Teaching Games For Understanding didasarkan pada enam komponen, dalam proses pelaksanaannya yaitu (1) permainan, (2) aplikasi permainan, (3) Kesadaran taktis, (4) Membuat keputusan yang tepat, (5) ) melakukan keterampilan, (6) Kinerja. Hasil penelitian tentang model pembelajaran permainan yang dilakukan oleh (Pearson, 2006) Sebaiknya 65\% dalam pembelajaran penjas lebih banyak dalam bentuk permainan. Hasil riset lain dari (Mandigo \& Holt, 2004) menjelaskan bahwa "Lebih dari 50\% waktu yang disediakan dalam program pendidikan jasmani di sekolah Alberta lebih banyak diarakan kepada pembelajaran permainan".

TGFU yang dilakukan dalam penerapan pola pemahaman permainan pada pembelajaran pendidikan jasmanai cenderung lebih menekankan pada model pendekatan taktis. (Subroto, 2001) menjelaskan bahwa melalui pendekatan latihan yang mirip dengan yang sesungguhnya, minat dan kegembiraan siswa akan meningkat". Peningkatan pengetahuan taktik, penting bagi siswa agar dia mampu menjaga keseimbangan keberhasilan pelaksanaan keterampilan gerak teknik yang sudah dimilikinya. Memperdalam pemahaman bermain dan meningkatkan kemampuan mengalihkan pemahaman secara lebih efektif dari penampilan dalam suatu permainan ke dalam permainan lainnya.

Pendekatan TGFU merupakan taktik pemainan untuk dapat dimengerti sebagai pengenalan pertama, siswa harus mengetahui kenapa dan kapan keterampilan itu diperlukan dalam konteks permainan, pelaksanaan teknis dalam keterampilan ditampilkan.

\section{METODE}

Maksud dan tujuan dari penelitian ini adalah untuk melihat pengaruh model pembelajaran TGFU terhadap hasil belajar keterampilan dasar sepakbola, maka metode penelitian yang digunakan dalam penelitian ini menggunakan metode eksperimen. (Ali, 2011) mengungkapkan bahwa: "Eksperimental menunjukan kepada suatu upaya sengaja dalam memodifikasi kondisi yang menentukan munculnya suatu peristiwa, serta pengamatan dan interpretasi perubahan-perubahan yang terjadi pada peristiwa itu yang dilakukan secara terkontrol." Lebih lanjut dalam desain eksperimen ada empat prinsip dasar yang perlu diperhatikan, yaitu: (1) penempatan subjek secara acak, (2) adanya perlakuan, (3) adanya mekanisme kontrol, (4) adanya ukuran keberhasilan (Maksum, 2012).

Lokasi dalam penelitian ini akan dilaksanakan di Sekolah Menengah Akhir (SMA) 3 Kota Serang. Alasan mengambil lokasi penelitian ini, belum adanya penelitian yang terkait tentang pendidikan jasmani, peneliti juga berkesempatan untuk mengenali dan menyelesaikan permasalahan yang ada di sekolah tersebut secara efektif dan efesien. Adapun karakteristik lokasi penelitian : Suhu udara mencapai $26^{\circ}-30^{\circ}$, Iklim Tropis, Terletak di perkampungan yang dikelilingi perumahan penduduk, dan Rata-rata setiap kelas berjumlah 40 siswa. 
Populasi dalam penelitian ini adalah seluruh siswa kelas X SMAN 3 Kota Serang yang berjumlah 11 kelas dan terdiri dari 440 siswa. Dalam penelitian ini teknik pengambilan sampling yang digunakan peneliti adalah teknik simpel Random Sampling. Peneliti hanya mengambil 40 siswa yang dijadikan sample dalam penelitian. Menurut (Maksum, 2012) "simple random sampling yaitu teknik sampling yang memberikan peluang yang sama bagi individu yang menjadi populasi untuk dipilih menjadi anggota sampel." Teknik random ini bisa dilakukan dengan cara undian. berdasarkan pendapat diatas dalam penelitian ini peneliti menggunakan teknik simple random sampling dengan cara undian.

Instrumen dalam penelitian ini menggunakan tes keterampilan dasar permainan sepakbola yang diukur dalam penelitian ini adalah passing-stopping, dribbling, dan shooting. Adapun tes pengukuran keterampilan dasar dalam permainan sepakbola (passing-stopping, dribbling, dan shooting). Penelitian ini dilaksanakan selama 16 pertemuan yang dilaksanakan 3 kali seminggu, jadi penelitian dilakukan kurang lebih selama 6 minggu, dengan langkah-langkah sebagai berikut

1. Pre Test

Pelaksanaan pre test dilakukan sebelum perlakuan diberikan. Pre test dilakukan untuk mengidentifikasi sejauh mana hasil belajar keterampilan dasar sepakbola yang telah dimiliki siswa. Untuk mengetahui skor pre test dilakukan dengan tes performa untuk hasil belajar keterampilan dasar sepakbola.

\section{Treatment}

Perlakuan ini dilakukan sebanyak 3 kali seminggu selama 6 minggu berturut-turut atau dengan kata lain sebanyak 16 kali pertemuan dan sudah termasuk satu pertemuan pre test dan satu pertemuan post test, jadi dapat dikatakan bahwa treatment di berikan sebanyak 14 pertemuan. Ini merujuk dari penelitian sebelumnya (Bayraktar, 2011) yang melakukan penelitian tentang penggunaan pembelajaran kooperatif selama 12 pertemuan kelas senam memiliki pengaruh yang signifikan terhadap keberhasilan akademik siswa, sikap, dan keterampilan latihan.

\section{Post test}

Setelah diberikan perlakuan selama 16 kali pertemuan yang dilakukan 3 kali setiap minggunya dengan durasi 2 x 45 menit setiap pertemuannya, selanjutnya sampel diberikan kembali tes keterampilan dasar permainan sepakbola, kemudian dianalisis untuk melihat peningkatan hasil belajar keterampilan dasar permainan sepakbola siswa.

Data hasil pengukuran selanjutnya diolah dan dianalisis dengan metode statistik dengan bantuan software Statistical Product For Service Solutions (SPSS) versi 20 Untuk data hasil belajar keterampilan dasar sepakbola, sebelum dilakukan uji statistik terlebih dahulu dilakukan konversi Z-Skor dan T-Skor untuk membandingkan dua sebaran skor yang berbeda. Berikut analisis data dengan menggunakan SPSS 20: 
1. Uji Normalitas yang digunakan pada penelitian ini adalah uji Shapiro-Wilk Test dengan taraf signifikansi $5 \%$ atau 0,05 .

2. Uji Homogenitas yang digunakan pada penelitian ini adalah uji Levane Statistic Test dengan taraf signifikansi $5 \%$ atau 0,05.

3. Teknik statistik untuk mencari pengaruh masing-masing variable menggunakan Uji-t sampel berpasangan (Paired Sample t-test).

\section{HASIL}

\section{Deskripsi Data}

Berikut disajikan deskripsi data T-skor perolehan keterampilan bermain sepakbola menggunakan model pembelajaran TGFU:

Tabel 1 Deskripsi Data T Skor Keterampilan Teknik Dasar Sepakbola

\begin{tabular}{ccccc}
\hline & & Tes Awal & Tes Akhir & Gain \\
\cline { 2 - 5 } Kelompok Model & $\mathrm{n}$ & 40 & 40 & 40 \\
pembelajaran TGFU & $\bar{X}$ & 89,50 & 110,50 & 20,99 \\
& Sd & 17,68 & 11,93 & 9,23 \\
\hline
\end{tabular}

Berdasarkan Tabel 1, t skor keterampilan teknik dasar sepakbola pada kelompok model pembelajaran TGFU pada pre-test memiliki rerata 89,50, dan simpangan baku 17,68, sedangkan untuk post-test memiliki rerata 110,50, dan simpangan baku11,93, sedangkan untuk gain memiliki rerata 20,99, dan simpangan baku 9,23 .

\section{Uji Normalitas}

Sebelum melakukan uji hipotesis terlebih dahulu dilakukan uji prasyarat yaitu uji normalitas. Uji normalitas dilakukan dengan menggunakan SPSS versi 20 . Kriteria sampel berdistribusi normal apabila Pvalue $>0,05$. Data hasil analisis uji normalitas tersebut dapat dilihat pada tabel 4.2 di halaman berikutnya.

Tabel 2. Uji Normalitas

\begin{tabular}{cccccc}
\hline No & Kelompok & $\mathrm{N}$ & $\begin{array}{c}\text { Asym. Sig } \\
\text { (p-value) }\end{array}$ & Kriteria & Keterangan \\
\hline 1 & Pretest Kelompok TGFU & 40 & 0.012 & $p<0,05$ & Tidak Normal \\
\hline 2 & Postest Kelompok TGFU & 40 & 0.057 & $p>0,05$ & Normal \\
\hline
\end{tabular}


Berdasarkan hasil uji analisis normalitas pada tabel di atas diketahui bahwa ada data P-value < 0,05 , sehingga data tersebut dinyatakan tidak normal. Dengan demikian maka pengujian hipotesis dilakukan dengan menggunakan uji nonparametrik.

\section{Uji Homogenitas}

Proses penghitungan uji homogenitas pada penelitian ini menggunakan SPSS versi 20. Syarat ini berkenaan dengan kesamaan varians gabungan terhadap keterampilan teknik dasar sepakbola pada kelompok model pembelajaran TGT dan kelompok model pembelajaran TGFU. Kriteria uji homogenitas terpenuhi apabila nilai P-value $>0,05$. Hasilnya dapat dilihat pada tabel 4.3 di halaman berikutnya dan untuk penghitungannya dapat dilihat pada lampiran.

Tabel 3. Uji Homogenitas

\begin{tabular}{cccccc}
\hline No & Kelompok & $\mathrm{N}$ & $\begin{array}{c}\text { Sig } \\
(\mathrm{p} \text {-value })\end{array}$ & Kriteria & Keterangan \\
\hline 1 & Pretest Kelompok TGFU & 40 & 0.941 & $\mathrm{p}>0,05$ & Homogen \\
\hline 2 & Postest Kelompok TGFU & 40 & 0.687 & $\mathrm{p}>0,05$ & Homogen \\
\hline
\end{tabular}

Berdasarkan tabel di atas, hasil uji kesamaan varians gabungan atau homogenitas data diketahui bahwa P-value $>0,05$. Hal ini menunjukan bahwa data tersebut berdistribusi homogen.

\section{Pengujian Hipotesis}

Setelah dilakukan uji normalitas dan homogenitas data, maka langkah selanjutnya adalah pengujian hipotesis. Uji tersebut dilakukan untuk menghasilkan kesimpulan dari permasalah penelitian. Dalam menguji data hasil tes awal dan tes akhir untuk mengetahui pengaruh perlakuan kelompok dilakukan uji nonparametrik dengan menggunakan Two Related Sample Tests, sedangkan untuk membandingkan hasil tes akhir kelompok TGFU dilakukan dengan Two Independent Sample tests guna mengetahui apakah terdapat peningkatan hasil belajar teknik dasar sepakbola dengan model pembelajaran TGFU. Berikut ini disajikan analisis Uji Two Related Sample tests keterampilan teknik dasar sepakbola pada kelompok yang diberi perlakuan pembelajaran TGFU:

Tabel 4. Analisis Two Related tests Keterampilan Teknik Dasar Sepakbola Kelompok TGFU

$$
\text { Postest - Pretest }
$$

Asymp. Sig. (2-tailed) $\quad .000$

Terlihat pada Tabel 4. nilai hasil uji Two Related Sample tests pada data pre-test dan post-test pada kelompok yang menggunakan pembelajaran TGFU menunjukan nilai signifikansi sebesar 0,000. 
Karena signifikansi pada data pre-test dan post-test pada kelompok yang menggunakan pembelajaran TGFU $<0,05$ maka dapat disimpulkan bahwa terdapat pengaruh pemberian model pembelajaran TGFU terhadap keterampilan teknik dasar sepakbola.

\section{PEMBAHASAN}

Berdasarkan hasil penelitian seperti yang telah dipaparkan oleh penulis di atas, secara keseluruhan pada pengujian hipotesis kedua menunjukkan bahwa pembelajaran TGFU memberikan pengaruh yang signifikan terhadap peningkatan skor tes keterampilan teknik dasar sepakbola. Peningkatan tersebut secara umum disebabkan karena penggunaan model pembelajaran TGFU merupakan hal yang baru bagi siswa, sehingga selama proses pembelajaran melalui sistem game-drill-game membuat siswa merasa senang dan termotivasi dalam mengikuti pembelajaran sepakbola.

Model pembelajaran TGFU yang diterapkan kepada siswa, membuat siswa terlibat aktif dalam permainan, mereka dapat melakukan teknik dasar dalam permainan sepakbola melalui pola bermain yang menyenangkan. Hasil observasi di lapangan, dengan pola bermain tersebut, siswa tidak cepat merasakan kebosanan, sehingga siswa dapat memperoleh pengalaman gerak dan pengalaman belajar teknik dasar sepakbola dengan jumlah waktu yang cukup banyak. Sistem game yang diterapkan dalam model TGFU bukan bersifat kompetitif atau turnamen, sehingga siswa tidak terbebani oleh kemenangan maupun kekalahan. Game yang dimainkan oleh siswa dalam pembelajaran sepakbola merupakan jenis game yang menyenangkan dengan pola modifikasi dengan tingkatan kesukaran yang bervariasi.

Selain pola game, dalam pembelajaran sepakbola melalui model TGFU juga menggunakan pola drill, yaitu proses perbaikan teknik dasar melalui latihan, baik kelompok maupun individu, sehingga dengan pola drill tersebut, siswa yang banyak melakukan kesalahan teknik dasar dalam permainan, dapat memperbaiki teknik dasar yang dia miliki melalui proses drill, sehingga setelah melakukan proses drill tersebut dapat mengeliminir kesalahan siswa pada saat melakukan game. Hasil observasi di lapangan, siswa yang telah melakukan proses drill menunjukan peningkatan dalam melakukan berbagai teknik dasar pada saat bermain sepakbola. Sehingga dengan model TGFU yang menekankan pada pola game-drillgame dapat meningkatkan teknik dasar sepakbola yang siswa miliki.

Hasil penelitian yang telah dipaparkan mendukung teori yang dikemukakan oleh Griffin, Mitchael, dan Oslin (1997) dalam (Metzler, 2000) menjelaskan bahwa: "pendekatan taktis adalah suatu proses yang terancam untuk menyempurnakan penampilan permainan yang di dalamnya terkandung penggabungan unsur kesadaran taktis dan pelaksanaan keahlian." Pendekatan taktis ini lebih menekankan pada penempatan belajar keterampilan teknik dalam konteks bermain dan memberikan kesempatan kepada peserta didik untuk melihat relevansi keterampilan teknik pada situasi bermain yang sebenarnya. 
Pendekatan taktis pada hakikatnya adalah suatu pendekatan pembelajaran keterampilan teknik dan sekaligus diterapkan dalam situasi permainan.

Kemudian (Subroto, 2001) menjelaskan bahwa pendekatan taktis adalah suatu cara untuk meningkatkan kesadaran peserta didik tentang konsep bermain melalui penerapan teknik yang tepat sesuai dengan masalah atau situasi dalam permainan. Dari penjelasan tersebut dapat disimpulkan bahwa pembelajaran dengan menggunakan pendekatan TGFU memberikan pengaruh terhadap perkembangan skill-nya, tingkat pengetahuan dan penampilan bermain siswa. Kesadaran taktik atau strategi dalam permainan harus dikembangkan kearah penguasaan keterampilan bermain" (Werner, Thorpe, dan Bunker, 1996) dalam (Metzler, 2000). Berdasarkan pemaparan di atas, maka pembelajaran TGFU dapat digunakan untuk meningkatkan keterampilan teknik dasar sepakbola pada siswa SMA.

\section{KESIMPULAN}

Berdasarkan data hasil penelitian yang telah dianalisis dan dibahas pada bab sebelumnya, maka disimpulkan bahwa Terdapat pengaruh yang signifikan model pembelajaran TGFU terhadap hasil belajar keterampilan teknik dasar dalam permainan sepakbola. Berlandaskan dari kesimpulan dari hasil penelitian yang telah penulis kemukakan, ada beberapa hal yang dapat disampaikan sebagai saran atau masukan yaitu, sebagai berikut untuk penelitian lebih lanjut, disarankan agar dikembangkan melalui kajian atau penggunaan variabel terikat yang berbeda seperti keterampilan bermain, variabel kebugaran jasmani, atau variabel sikap. Selain itu diharapkan pada penelitian selanjutnya dapat dikembangkan lagi dengan variabel atribut seperti kemampuan motorik, jenis kelamin, kelompok usia dan lain sebagainya atau penerapan pada jenjang pendidikan yang lebih tinggi lagi.

\section{REFERENSI}

Ali, M. (2011). Memahami Riset Prilaku Dan Sosial. Bandung: CV Pustaka Cendikia Utama.

Bayraktar, G. (2011). The effect of cooperative learning on students' approach to general gymnastics course and academic achievements. Educational Research and Reviews.

Budi, D. R., Hidayat, R., \& Febriani, A. R. (2019). The Application of Tactical Approaches in Learning Handballs. JUARA : Jurnal Olahraga. https://doi.org/10.33222/juara.v4i2.534

Budi, Didik Rilastiyo (2015) Pengaruh Modifikasi Permainan Vobas dan Kebugaran Jasmani Terhadap Peningkatan Kerjasama Siswa Dalam Pembelajaran Penjas Di SMP. S2 thesis, Universitas Pendidikan Indonesia

Lickona, T. (2012). Educating For Character. Canada: Irvin Parkins Associates. Inc Batam Books.

Maksum, A. (2012). Metodelogi Penelitian Dalam Olahraga. Surabaya: Unesa University Press.

Mandigo, J. L., \& Holt, N. L. (2004). Reading the Game: Introducing the Notion of Games Literacy. Physical Education and Kinesiology at Brock University. 
Metzler, M. W. (2000). Intructional Model For Physical Education. Massachusetts: Allyn and Bacon, Inc.

Pearson, P. (2006). Game Sense Online-Utilising the Web for the Professional Development of Physical and Health Education Teachers. Australia: University of Wollongong.

Slavin, R. E. (2008). Cooperative Learning. Teori, Riset dan Praktik. Bandung: Nusa Media.

Solihatin, E., \& Raharjo. (2011). Cooperative Learning. Jakarta: PT Bumi Aksara.

Subroto, T. (2001). Pembelajaran Keterampilan dan Konsep Olahraga Di Sekolah Dasar. Jakarta: DEPDIKNAS.

Sucipto, dkk. (2000). Sepakbola. Bandung: FPOK UPI. 